\title{
PROSES PENGAMBILAN KEPUTUSAN DENGAN BERPIKIR KRITIS PADA PASIEN GAWAT DARURAT DALAM MEMBERI ASUHAN KEPERAWATAN
}

\section{Pebi Septrian Sari}

\author{
febi.septrian03@gmail.com
}

\section{LATAR BELAKANG}

Rumah Sakit merupakan tempat pelayanan kesehatan yang sering dikunjungi masyarakat untuk melakukan upaya kesehatan agar dirinya dapat sembuh kembali. Didalam suatu Rumah Sakit terdapat orang-orang yang mempunyai perbedaan dalam hal kesehatanya. Orang-orang yang datang ke Rumah Sakit kemungkinan kondisinya sudah dalam keadaan darurat atau kondisinya bisa ditangani dengan cepat dan segera. Pasien pertama kali datang dan harus segera ditangani ditempatkan di Ruang IGD atau Instalasi Gawat Darurat. Ruang gawat darurat merupakan pelayanan pertama kali dari suatu rumah sakit untuk menyelamatkan pasien dalam waktu yang cepat dan tindakan yang tepat. Kinerja perawat yang tepat dapat menyelamatkan banyak orang.

Setelah masuk ke ruangan IGD perawat melakukan pengumpulan data untuk mengidentifikasi masalah kedsehatan pasien tersebut dengan mengobservasi keadaan umum pasien dari awal masuk, melakukan pengkajian tanda-tanda vital, melakukan anamnesa keluhan dan pemeriksaan fisik. Setelah mengetahui hasil dari pemeriksaan bahwa pasien dalam keadaan darurat dan perawat harus mengambil keputusan tindakan apa yang akan dilakukan, perawat juga harus mempertimbangkan faktor yang mempengaruhi proses pengambilan keputusan itu untuk memenuhi kebutuhan pasien. Dalam mengambil keputusan perawat juga harus punya kemampuan berpikir kritis agar keputusan yang diambil tepat dalam memberi Sebagai perawat kita memiliki tanggung jawab dan kewenangan untuk memilih langkahlangkah keperawatan yang diperlukan sesuai dengan standar keperawatan.

Pengambilan keputusan ini pengaruhnya pada proses keperawatan,dimana yang kita tahu bahwa proses keperawatan terdiri dari pengkajian, diagnosa keperawatan, intervensi, impelementasi sampai evaluasi, karena proses keperawatan merupakan bentuk pendekatan untuk memecahkan masalah yang mendukung kemampuan perawat dalam mengatur dan memberi asuhan keperawatan. Asuhan keperawatan yang diberikan kepada pasien lebih 
maksimal jika melibatkan keluarga. Adapun pengertian dari asuhan keperawatan adalah faktor penting dalam kelangsungan hidup pasien dan aspek-aspek pemeliharaan, rehabilitatif, dan prefentif perawatan kesehatan.

\section{METODE}

Sebagai contoh peneliti melakukan kegiatan pengumpulan data dengan wawancara semi terstruktur dengan mengajukan beberapa pertanyaan pada perawat seperti apa yang anda lakukan pada saat pasien masuk ke IGD ? Bagaimana cara menilai pasien ? Bagaimana cara menganalisis masalah ? Bagaimana membuat keputusan dari masalah tersebut ? Apa dampak masalah yang anda hadapi?

\section{HASIL}

Hasil Penelitian ini menghasilkan empat tema yaitu tindakan perawat dalam proses pengambilan keputusan untuk mendapatkan penanganan terlebih dahulu sesuai dengan tingkat kegawatdaruratan pasien (triase), konflik kerjasama dokter-perawat dalam pengambilan keputusan untuk mendapatkan penanganan terlebih dahulu sesuai dengan tingkat kegwatdaruratan pasien (triase), kendala pelayanan IGD, dan dilema yang dihadapi perawat.

1. Tindakan Perawat dalam Proses Pengambilan Keputusan, terdiri dari pengumpulan data dan melakukan klasifikasi pasien, secara umum partisipan melakukannya pada setiap pasien yang masuk di IGD dengan melihat kondisi psien pada waktu pertama kali masuk.

Contoh dialog : " pertama pastinya kita lihat dulu kondisi pasienya gimana, datang dengan keluhan sesak atau biasa aja, kalau keluhannya biasa saja yang dapat kita lakukan pertama memeriksa tanda-tanda vital"

2. Konflik Kerjasama Dokter-Perawat dalam pengambilan keputusan, Perasaan perawat menilai masalah pasien. Yang dirasakan perawat ketika menilai pasien adalah merasa yakin kebeneranya sudah sesuai kondisi pasien dari hasil pemeriksaan,kadang merasa bingung, ada juga yang kesulitan karena riwayatnya tidak diketahui dan keluarga juga tidak tahu, seperti pada pasien yang tidak sadar. Kurangnya pengakuan dokter terhadap kemampuan perawat padahal perawat sudah menentukan bahwa kondisi pasien gawat, bahkan juga mengusulkan dilakukan tindakan tetapi dokter menolak .

Contoh dialog : "susahnya kita menerima pasien yang tidak sadar, dan riwayat penyakitnya tidak diketahui keluarga, ya terus disampaikan ke dokter" 
3. Kendala pelayanan, Karena IGD yang mestinya hanya melayani pasien-pasien sesuai kriteria kedaruratan, dan memerlukan observasi dalam beberapa jam, tetapi disini menerima pasien harusnya sudah bisa di tempatkan di ruang rawat.

Contoh dialog : "Ruang IGD penuh karena adanya pasien titipan"

4. Dilema yang dihadapi Perawat, konflik dengan keluarga pasien karena keluarga berharap datang langsung ditangani dan diberikan pengobatan. Perawat dihadapkan diantara pilihan yang menyulitkan . perawat menerima pasien kecelakaan dengan cidera kepala berat harus diberi pertolongan, tapi dokter ahli tidak ada ditempat, mau dirujuk ke rumah sakit yang ada dokter ahlinya, tapi masih nungu keluarga.

Contoh dialog : "keluarga pengennya semua cepet ditangani, ya kadang bentrok sama keluarga atau pasienya sih, itu ga bisa dipungkiri”

\section{PEMBAHASAN}

Sebelum menentukan triase perawat IGD mengumpulkan data untuk mengidentifikasi masalah dengan melakukan observasi keadaan umum pasien saat masuk, pengukuran tandatanda vital, menentukan anamnesa keluhan dan melakukan pemeriksaan fisik. Berdasakan Withby et al (1997) hasil penelitannya menunjukkan bahwa perawat triase dalam menentukan urgensi pasien menggunakan data dari hasil pengkajian yang dikumpulkan, penampilan pasien, gejala,dan tanda-tanda fisiologis.

Menurut Anderson, Omberg \& Svedlund,(2006) bahwa ketika perawat memutuskan keputusan triase, perawat harus melakukan penilaian terhadap status klinis pasien dengan mengajukan pertanyaan, melihat,dan memeriksa. Pemeriksaan fisik juga membantu perawat dalam mengambil keputusan. Sistem tingkat kedaruratan triase mempunyai arti yang penting karena triase merupakan suatu proses mengkomunikasikan kondisi kegawatdaruratan pasien di IGD. Jika data hasil pengkajian triase dikumpulkan secara akurat dan tersusun,maka IGD dapat menggunkan keterangan untuk menilai, menganalisis berapa lama pasien akan dirawat, berapa hari pasien harus dirawat inap dan sebagainya.

Perawat yang bertugas diruang IGD mengambil keputusan bisa berdasarkan pengalaman terdahulu dalam menangani pasien kasus rutin dan telah biasa dihadapi perawat membuat mereka melngingat pengalaman yang pernah dijalani untuk menangani pasien pada kasus-kasus yang mirip dengan kasus sebelumnya. Bisa juga berdasarkan prosedur tetap yang ada, dimana perawat meningat langkah-langkah penanganan pasien sesuai dengan standar 
Rumah Sakit, dan Berdasarkan pendidikan perawat mengambil keputusan dengan mengingat teori yang pernah diperoleh selama pendidikan terakhir berdasarkan pertimbangan Dokter.

Untuk kasus yang luar biasa, yang bukan masalah rutin terjadi, perawat bisa meminta pertimbangan pada Dokter Rumah Sakit.

Fungsi perawat di IGD adalah melakukan triase, mengkaji dan menetapkan prioritas yang lebih luas terhadap kondisi klinis yang bersifat mendadak mulai dari ancaman nyawa sampai kondisi kritis. Dijelaskan bahwa perawat yang dimaksud adalah mereka yang berkompeten, mengikuti pelatihan tentang kegawatdaruratan. Konflik yang terjadi adalah perawat bekerja melakukan triase tetapi hasil penilaian dan keputusan perawat diabaikan, bahkan pada waktu malam hari dokter lebih banyak dikamar dokter,jika istrahat / tidur susah dibangunkan, kadang juga sampai lama sekali jauh melebihi waktu tunggu di IGD, dokter yang bertugas di IGD tiap jadwal tugas hanya satu dan hanya menerima laporan. Jika di IGD dalam keadaan ramai dengan julah pasien yang banyak ini merupakan suatu pertentangan tersendiri, karena hal ini merupakan sesuatu yang tidak menyenangkan baik dari sisi kepercayaan kemampuan maupun secara mental. Konflik yang terjadi tersebut membuat perawat merasa tidak nyaman dan dianggap tidak mampu. Konflik yang dirasakan perawat akan memberikan efek negatif pada kondisi yang lain, karena bekerja di ruang IGD sudah memberikan tekanan mental tersendiri pada perawat dimana beban kerja mental perawat di ruang IGD dapat berupa tekanan waktu dalam membuat keputusan yang tepat dan cepat untuk melakukan tindakan terhadap pasien juga harus menghadapi keluarga pasien. Dengan adanya konflik-konflik yang dialami perawat bisa menyebabkan kesalahan, dengan sejumlah beban mental yang dihadapi menjadikan perawat kadang merasa tegang, tidak bisa mengatasi kesulitan sendiri dan tidak mudah dalam mempertimbangkan suatu hal yang terkait dengan tugasnya sebagai perawat.

Di ruang rawat IGD perawat memiliki beban kerja yang tinggi terkait adanya penitipan pasien di IGD selain pasien observasi IGD itu sendiri, tindakan-tindakan prosedural lain seperti laparaskopi dan operasi. Untuk pasien titipan tersebut lamanya bisa berhari-hari, hal itu juga yang mempengaruhi kinerja perawat. Pengaturan ruangan di IGD merupakan bagian dari sistem tingkat krdaruratan pasien. Pasien yang sudah dipilah berdasarkan tingkat kegawatannya, hendaklah masuk keruang triase sesuai dengan kondisinya, hal ini memudahkan perawat dalam bekerja untuk menentukan mana pasien yang harus didahulukan atau prioritas dan mana pasien yang penanganannya bisa ditunda. Jika ruangan yang tersedia sesuai tingkat kegawatan pasien tersebut tidak tersedia, maka hal ini akan mempersulit perawat untuk bekerja atau bertindak cepat untuk menangani pasien tersebut, terlebih jika jumlah pasien yang datang 
banyak dalam waktu yang bersamaan. Terkadang terjadi permasalahan dengan keluarga pasien yang berawal dari petugas yang tidak menjalankan tugasnya sesuai perannya, yang mana petugas tersebut hendaknya mengatur situasi yang ada dengan mengatur keluarga pasien yang mendampingi sesuai dengan aturan di IGD dengan menentukan jumlah keluarga yang masuk. Komunikasi yang baik antara petugas dan keluarga akan memberikan pengertian, dan pelayanan yang diberikan petugas tidak terganggu.

Interaksi yang sering dilakukan pasien dan keluarga didalam rumah sakit adalah perawat, berbagai ketidakpuasaan, kemarahan dari keluarga sering ditunjukan kepada perawat. Pasien yang di IGD masuk pada prioritas rendah merasa diabaikan ,dan lambat dalam menangani. Menurut Cone,K., \& Murray, R (2000) bahwa perawat triase penting memiliki karakteristik kemampuan dalam penilaian, berfikir kritis, dan berkomunikasi dengan baik. Proes keperawatan berjalan dengan baik apabila adanya komunikasi antara pasien dan perawat mengenai informasi tentang masalah yang terjadi. Sehingga perawat harus memberikan keputusan yang harus diterima pasien.

\section{PENUTUP}

Pengambilan keputusan mengenai triase yang dilakukan perawat IGD sangat ditentukan oleh tingkat pengetahuan perawat. Perawat IGD dalam mengambil keputusan mengalami suatu konflik kerjasama, dimana perawat sudah menilai dan melakukan pemilahan terhadap pasien yang masuk tapi dokter sangat sulit untuk bekerjasama karena merasa lebih kompeten. Dimana akhirnya terjadi tindakan yang lambat karena harus menunggu dokter. Dan perawat juga sudah mampu melakukan asuhan keperawatan yang baik dalam melakukan penanganan karena pengalaman terdahulu mengingat kasus-kasus yang pernah terjadi dipengaruhi juga karena waktu lama kerja.

\section{DAFTAR PUSTAKA}

Simamora, R. H. (2019). Menjadiperawat yang: CIH'HUY. Surakarta: Kekata Publisher.

Simamora,R.H. (2005). Hubungan Persepsi Perawat Pelaksana Terhadap Penerapan Fungsi Pengorganisasian Yang Dilakukan Oleh Kepala Ruangan Dengan Kinerjanya Diruang Rawat Inap RSUD Koja Jakarta Utara (Doctoral dissertation, Tesis FIK UI, Tidakdipublikasikan).

Khairina,ilfa,. Malini,H,.\& Huriani E. (2018). Faktor-faktor Yang Berhubungan Dengan Pengambilan Keptusan Perawat Dalam Ketepaatan Triase Di Kota Padang. Indonesian Journal for Health Sciences.2(01):1-6.

Deniati, K,. Anugrahwati, R.,\& Suminarti, T. (2018). Pengaruh Berfikir Kritis Terhadap Kemampuan Perawat Dalam Melakukan Asuhan Keperawatan Di Rumah Sakit Hermina Bekasi Tahun 2016. Jurnal Kesehatan Holistik. Vol 12(1): 21-25. 
Widodo,N.W,. Wungow,H,.\& Hamel,S.R. (2016). Hubungan Peran Ketua Tim Dengan Kinerja Perawat Pelaksana Dalam Pendokumentasian Asuhan Keperawatan Di Irina F RSUP Prof DR.R. D. Kandou. ejournal Keperawatan. Vol 4(2):1-5.

Supratti,. Ashriady . (2016). Pendokumentasian Standar Asuhan Keperawatan Di Rumah Sakit Umum Daerah Mamuju,Indonesia. Jurnal Kesehatan MANARANG. Vol 2(1): 44-51.

Faidah, N,. Ratnawati, R,.\& Setyoadi. (2013). Pengalaman Perawat Dalam Pengambilan Keputusan Triage Di Instalasi Gawat Darurat RSUD RAA Soewondo Pati. Jurnal Keperawatan dan Kesehatan Masyarakat. 1(2): Vol 35-42.

Triwijayanti, A,. Rodhiyatun,. Rohman,N.R,.dkk. (2020). Gambaran Psikologis Kepuasan Keluarga Dalam Menerima Asuhan Keperawatan. Jurnal IImu Keperawatan Jiwa. Vol 3(1): 75-82.

Pashar, R,. Dwiantoro, L. (2020). Pengaruh Empowerment Terhadap Pengambilan Keputusan Perawat. Journal of Holistic Nursing Science. Vol 7(2): 124-132.

Koerniawan, D,. Daeli, E.N ,.\& Srimiyati. (2020). Aplikasi Standar Proses Keperawatan: Diagnosis,Outcome,dan Intervensi Pada Asuhan Keperawatan. Jurnal Keperawatan Silampari. Vol 3(2): 739-751.

Ali, U,. Latif, A,. \& Kadir, A. (2014). Faktor-faktor Yang Berhubungan Dengan Mutu Pelayanan Keperawatan Di Ruang IGD RSUP Dr. Wahidin Sudirohusodo Makassar. Vol 4(2):228-235.

Ardiyani,M.V,. Andri, T.M,. \& Eko, K.R. (2015). Analisis Peran Perawat Triage Terhadap Waiting Time dan Lenght Of Stay Pada Ruang Triage Di Instalasi Gawat Darurat Rumah Sakit dr Saiful Anwar Malang. Vol 3(1): 39-50. 